\title{
Pancreatic islets from dexamethasone-treated rats show alterations in global gene expression and mitochondrial pathways
}

\author{
Letícia P. Roma ${ }^{1,2}$, Kleber L. A. Souza ${ }^{1}$, Everardo M. Carneiro ${ }^{1}$, Antonio C. Boschero ${ }^{1}$ \\ and José R. Bosqueiro ${ }^{3}$ \\ ${ }^{1}$ Laboratory of Endocrine Pancreas and Metabolism, Department of Physiology and Biophysics, Institute of Biology, State \\ University of Campinas (UNICAMP), Campinas, SP, Brazil \\ ${ }^{2}$ Institute of Biomedical Sciences, Department of Physiology and Biophysics, University of São Paulo, São Paulo, Brazil \\ ${ }^{3}$ Laboratory of Endocrine Pancreas Physiology, Department of Physical Education, Faculty of Sciences, São Paulo State \\ University (UNESP), Bauru, SP, Brazil
}

\begin{abstract}
Chronic administration of glucocorticoids (GC) leads to characteristic features of type 2 diabetes in mammals. The main action of dexamethasone in target cells occurs through modulation of gene expression, although the exact mechanisms are still unknown. We therefore investigated the gene expression profile of pancreatic islets from rats treated with dexamethasone using a cDNA array screening analysis. The expression of selected genes and proteins involved in mitochondrial apoptosis was further analyzed by PCR and immunoblotting. Insulin, triglyceride and free fatty acid plasma levels, as well as glucose-induced insulin secretion, were significantly higher in dexamethasone-treated rats compared with controls. Out of 1176 genes, 60 were upregulated and 28 were down-regulated by dexamethasone treatment. Some of the modulated genes are involved in apoptosis, stress response, and proliferation pathways. RT-PCR confirmed the cDNA array results for 6 selected genes. Bax a protein expression was increased, while Bcl-2 was decreased. In vivo dexamethasone treatment decreased the mitochondrial production of $\mathrm{NAD}(\mathrm{P}) \mathrm{H}$, and increased ROS production. Concluding, our data indicate that dexamethasone modulates the expression of genes and proteins involved in several pathways of pancreatic-islet cells, and mitochondria dysfunction might be involved in the deleterious effects after long-term GC treatment.
\end{abstract}

Key words: Gene expression — Cell viability — Insulin secretion — Diabetes

Abbreviations: FFA, free fatty acid; GC, glucocorticoids; JNK, c-Jun N-terminal kinases; ROS, reactive oxygen species.

\section{Introduction}

Glucocorticoids (GCs) induce insulin resistance (Hoogwerf and Danese 1999; Rafacho et al. 2007) and impair insulin secretion from pancreatic $\beta$-cells (Kawai and Kuzuya 1977; Delaunay et al. 1997; Patel et al. 2006). Additionally, high

Correspondence to: Leticia Prates Roma, Institute of Biomedical Sciences, Department of Physiology and Biophysics, University of São Paulo, Av. Prof. Lineu Prestes 1524, Butantã, 05880-900 São Paulo/SP, Brazil

E-mail: roma.leticia@gmail.com levels of GC also lead to an increase in hepatic gluconeogenesis, (Lenzen and Bailey 1984) which contributes to the diabetic status. On the other hand, despite extensive studies, the molecular mechanisms involved in GC-induced diabetes are only partially known.

GC action on target cells is primarily driven by activation of cytoplasmic GC receptors (GCR). The complex GC-GCR is translocated to the nucleus and regulates gene expression (Beato 1991; Auphan et al. 1995; Schaaf and Cidlowski 2002) through either direct binding of GCR homodimers to DNA enhancer sequences - known as glucocorticoid response elements (Beato et al. 1995) - or 
indirectly through DNA binding-independent mechanisms involving protein to protein interactions (Beato 1991; Auphan et al. 1995). Chronic administration of GC increases plasma insulin levels (Lenzen and Bailey 1984; Rafacho et al. 2007). GC can directly affect insulin secretion through binding to GCR present in $\beta$-cells (Fischer et al. 1990). This GC action may lead to a stimulatory (Nicod et al. 2003) or inhibitory effect (Lambillotte et al. 1997; Jeong et al. 2001) on insulin release, depending on the concentration, time of exposure (Lambillotte et al. 1997) and experimental procedures used.

GCs are used in clinical practice as anti-inflammatory and immunosuppressor agents (Auphan et al. 1995; Schmidt et al. 2004). The immunusuppressor effects are mediated by the induction of apoptosis in cells of the immune system and other cell types (Schmidt et al. 2004). A number of genes, including cellular oncogenes, $\mathrm{Bcl}-2$, transcription factors, and the tumor suppressor gene p53, have been implicated in the control of apoptosis in mammalians (Zhang et al. 1999; Eizirik and Mandrup-Poulsen 2001; Kutlu et al. 2003; Souza et al. 2004). In fact, proteins from the Bcl-2 family are crucial for the activation of apoptosis by the intrinsic pathway (mitochondrial) (Cory and Adams 2002). Proand anti-apoptotic Bcl-2 protein family members located on the surface of mitochondrial membrane compete to regulate the membrane integrity and cytochrome $c$ release. After its release by activated pro-apoptotic proteins (Bax, Bik, Bak) (Adams and Cory 2001), cytochrome $c$ binds to Apaf-1 forming the apoptosome, which leads to cleavage of procaspase-9 to form activated caspase-9 (Kaufmann and Hengartner 2001). Apoptosis is achieved through cleavage of specific substrates such as laminin, cytoskeletal proteins, poly-ADP ribose polymerase, and downstream caspases (Cory and Adams 2002). Anti-apoptotic proteins, including $\mathrm{Bcl}-2$ and $\mathrm{Bcl}-\mathrm{xl}$, protect cells mainly by modulating the activity of channels, such as the voltage-dependent anion channels (VDAC), and inhibiting pore formation on the mitochondrial surface.

In this study, we performed gene expression screening by cDNA array to identify potential pathways and functionally relevant gene clusters in pancreatic islets from dexamethasone-treated animals at an early time point when $\beta$-cell function is altered but cell apoptosis is still undetected (Rafacho et al. 2009). Using this approach, we found evidence that dexamethasone treatment modulates gene expression of several pathways, reducing the expression of anti-apoptotic and increasing the expression of pro-apoptotic proteins, namely the $\mathrm{Bcl}-2$ members. We also found that dexamethasone decreases mitochondrial metabolism and increased ROS production indicating that $\beta$-cell death after long-term exposure to GC may start with modulation of mitochondrial pathways leading to mitochondrial dysfunction and diabetes.

\section{Materials and Methods}

\section{Chemicals}

Dexamethasone phosphate (Dexanil $\left.{ }^{\circledR}\right)$ was purchased from Acta (Campinas, Sao Paulo, Brazil). Non-esterified-fatty-acids (NEFA) were from Wako Chemicals USA, Inc. (Richmond, USA). Triglycerides and total cholesterol were from Roche Diagnostics (Mannheim, German). Dextrose, $\mathrm{NaCl}, \mathrm{KCl}$, $\mathrm{CaCl}_{2}, \mathrm{MgCl}_{2}, \mathrm{NaHCO}_{3}, \mathrm{KOH}$ and $\mathrm{Na}_{2} \mathrm{SO}_{4}$ were from Mallinckrodt Baker, Inc. (Paris, France). Collagenase, Hepes, albumin, activated charcoal and dextran were from Sigma (St. Louis, USA). Ethanol, methanol, chloroform and phenol were from Synth (Diadema, Sao Paulo, Brazil). SDS-PAGE and immunoblotting were performed using Bio-Rad systems (Richmond, USA). All chemicals used for immunoblotting were from Sigma (St. Louis, USA) and all reagents used in the experiments for RT-PCR were from Invitrogen (Carlsbad, USA). Nitrocellulose membranes (Hybond N, $0.45 \mu \mathrm{m}$ ) were from Amersham (Buckinghamshire, United Kingdom). Anti$\mathrm{Bcl} 2$ (rabbit polyclonal, sc-7382, dilution $1: 500$ ), anti-Bax a (rabbit polyclonal, sc-493, dilution 1:500) and anti-Bcl-xl (rabbit polyclonal, sc-7195, dilution $1: 500$ ) antibodies were from Santa Cruz Biotechnology (Santa Cruz, USA).

\section{Animals, dexamethasone treatment and islet isolation}

Ninety-day-old Wistar rats were provided by the Animal Breeding Center of the University of Campinas (Campinas, SP, Brazil). All experimental procedures conformed to The Guiding Principles for the Care and Use of Animals (DHEW Publication, NIH 80-23) and were approved by the Committee for Ethics in Animal Experimentation of the University of Campinas (Brazil). Dexamethasone group received daily dexamethasone injections at a concentration of $1 \mathrm{mg} / \mathrm{kg} /$ day (i.p.), for 5 consecutive days, dissolved in saline. The control group received an equal amount of vehicle. For each set of experiments, islets from five adult male Wistar rats were obtained by collagenase $(1 \mathrm{mg} / \mathrm{ml})$ digestion of pancreata and isolated by centrifugation (2000 rpm for 10 minutes) on Ficoll gradients.

\section{Insulin secretion}

Groups of five islets from dexamethasone-treated and from control animals were first incubated for $45 \mathrm{~min}$ at $37^{\circ} \mathrm{C}$ in Krebs-bicarbonate buffer (containing $5.6 \mathrm{mmol} / \mathrm{l}$ glucose and equilibrated with $95 \% \mathrm{O}_{2}-5 \% \mathrm{CO}_{2}, \mathrm{pH} 7.4$ ). The solution was then replaced with fresh Krebs-bicarbonate buffer and the islets were incubated for $1 \mathrm{~h}$ with medium containing 2.8, 8.3 or $22 \mathrm{mmol} / \mathrm{l}$ of glucose. Insulin secretion was measured by radioimmunoassay (RIA) using a guinea-pig anti-rat insulin antibody and rat insulin as standard. 
Metabolic, hormonal and biochemical measurements

On the day following the last dexamethasone administration, fasted $(12 \mathrm{~h})$ rats were killed and blood samples were collected. Blood glucose levels were measured with a glucometer ("one touch" - Johnson \& Johnson, São Paulo, Brazil). Serum insulin levels were detected by RIA. Triglycerides, NEFA, and total cholesterol levels were determined by ELISA, according to the manufacturer's instructions.

\section{cDNA array analyses}

The gene expression profile was analyzed by a cDNA expression array (Clontech Laboratories, Atlas ${ }^{\mathrm{TM}}$ rat cDNA array II) representing 1176 genes. Total RNA was extracted from approximately 1000 islets using Trizol reagent (InVitrogen). After extraction, the samples were treated with DNAse I and RNAse Out (Invitrogen). The quality and purity of the RNA were checked by agarose gel electrophoresis and by PCR. Radiolabeled ( $\left[{ }^{33} \mathrm{P}\right]$ dATP) cDNAs were prepared using 5-10 $\mu \mathrm{g}$ of total RNA and a gene-specific CDS primer mix (Clontech Labs, Palo Alto, USA), and processed as recommended by the manufacturer. Following hybridization and washing, the membranes were exposed to a phosphoimager screen (Molecular Dynamics, San José, USA) and scanned using a Storm 840 Scanner (Molecular Dynamics). The images were analyzed by QuantityOne (Bio-rad) and normalized using three internal control genes. Only changes in gene expression that were reproducible and higher than the cut-off of two-fold or lower than half in two independent experiments were considered valid. The evaluation of fold changes was performed using a Microcal Origin program, version 4.10 (Microcal Software, Inc., Northampton, USA).
Semi-quantitative analysis of $m R N A$ by RT-PCR

Total cellular RNA was extracted from groups of 500 islets using Trizol reagent. Reverse transcription was carried out with $2 \mu \mathrm{g}$ of total RNA using a reverse transcriptase (Superscript II, InVitrogen) and random hexamer primers, according to the manufacturer's instructions. RT-PCR assays were done using recombinant Taq DNA polymerase with $10 \mathrm{pmol}$ of each primer in a final volume of $50 \mu \mathrm{l}$. The primers were designed and synthesized based on the published gene sequence, as shown in Table 1. The PCR was carried out in a thermal cycler (model 9700, Applied Biosystems, Foster City, USA) with an initial denaturation step at $94^{\circ} \mathrm{C}$ for $3 \mathrm{~min}$, subject to variable number of cycles of denaturation at $94^{\circ} \mathrm{C}$ for $30 \mathrm{~s}$, annealing for $30 \mathrm{~s}$, elongation at $72^{\circ} \mathrm{C}$ for $45 \mathrm{~s}$ and a final elongation step at $72^{\circ} \mathrm{C}$ for $7 \mathrm{~min}$. The melting temperature and number of cycles were $61^{\circ} \mathrm{C}$ and 34 cycles for $\mathrm{Bcl}-2,60^{\circ} \mathrm{C}$ and 35 cycles for $\mathrm{Bcl}-\mathrm{xl}$ , $59^{\circ} \mathrm{C}$ and 34 cycles for Bax $\alpha, 60^{\circ} \mathrm{C}$ and 37 cycles for Bad, $59^{\circ} \mathrm{C}$ and 32 cycles for JNK, $59^{\circ} \mathrm{C}$ and 32 cycles for Fas, $59^{\circ} \mathrm{C}$ and 29 cycles for RPS-29. The cycle numbers were defined after titration between 20 and 45 cycles and were within the logarithmic phase of amplification. PCR products were run on $1 \%$ agarose gels, and the DNA was visualized by ethidium bromide staining. The band intensities were determined by digital scanning followed by quantification using Scion Image analysis software (Scion Corp., Frederick, USA).

\section{Tissue extracts and immunoblotting}

After isolation, the islets were homogenized by sonication in ice cold buffer (10\% Triton-X 100, 100 mmol/1 Tris (pH 7.4), 10 $\mathrm{mmol} / \mathrm{l}$ sodium pyrophosphate, $100 \mathrm{mmol} / \mathrm{l}$ sodium fluoride,

Table 1. Primers for selected genes used in the RT-PCR

\begin{tabular}{|c|c|c|c|c|}
\hline Gene & Primer & Primer sequence $\left(5^{\prime}-3^{\prime}\right)$ & Gene Bank accession number & Product sizes \\
\hline \multirow[t]{2}{*}{$\mathrm{Bcl}-2$} & $\mathrm{~F}$ & GTATGATAACCGGGAGATCG & NM016993 & 611 \\
\hline & $\mathrm{R}$ & AGCCAGGAGAAATCAAACAG & & \\
\hline \multirow[t]{2}{*}{ Bcl-xl } & $\mathrm{F}$ & GTGGCTGGTGTAGTTCTGCTGG & U72350 & 314 \\
\hline & $\mathrm{R}$ & AACAAGGCAGGCTCTTCTCCC & & \\
\hline \multirow[t]{2}{*}{$\mathrm{Bad}$} & $\mathrm{F}$ & CAGTGATCTGCTCCACATTC & NM022698 & 330 \\
\hline & $\mathrm{R}$ & ATGATAGGACAGCACCCAGT & & \\
\hline \multirow[t]{2}{*}{ Bax $a$} & $\mathrm{~F}$ & AAGAAGCTGAGCGAGTGTCT & U49729 & 360 \\
\hline & $\mathrm{R}$ & CAAAGATGGTCACTGTCTGC & & \\
\hline \multirow[t]{2}{*}{ FasR } & $\mathrm{F}$ & GACTTTAGCTGGGCAGATGT & D26112 & 692 \\
\hline & $\mathrm{R}$ & CAGAAGAGAGCATGGGAAAT & & \\
\hline \multirow[t]{2}{*}{ JNK } & $\mathrm{F}$ & GCCATCATGAGCAGAAGTAA & NML27129 & 210 \\
\hline & $\mathrm{R}$ & GCTTAGCATGGGTCTGATTC & & \\
\hline \multirow[t]{2}{*}{ RPS-29 } & $\mathrm{F}$ & AGGCAAGATGGGTCACCAGC & NM012876 & 202 \\
\hline & $\mathrm{R}$ & AGTCGAATCATCCATTCAGGTCG & & \\
\hline
\end{tabular}

F, forward primer; R, reverse primer; RPS-29, ribosomal protein S29; JNK, c-Jun N-terminal kinase; FasR, Fas receptor. 


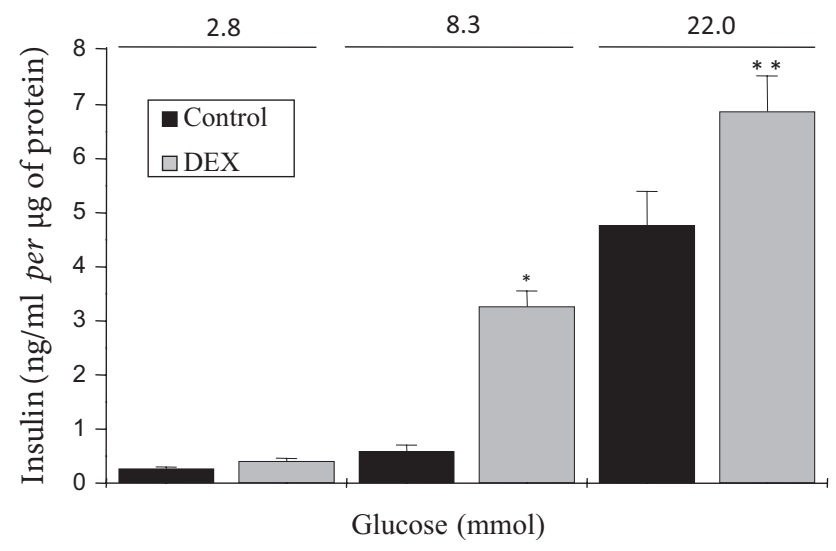

Figure 1. Effect of dexamethasone on insulin secretion in isolated rat islets. Rats were treated with dexamethasone ( $1 \mathrm{mg} / \mathrm{kg} /$ day) for 5 days. After isolation, groups of 5 islets were incubated in HEPES-bicarbonate buffer containing 2.8, 8.3 or $22 \mathrm{mM}$ glucose. Columns represent the cumulative $1 \mathrm{~h}$ insulin secretion and are means \pm SEM of 3 independent experiments $(n=18)$. The insulin secretion was normalized by total islet protein content. Means with a different letter above columns are significantly different $(p<0.05)$. DEX, dexamethasone group.

$10 \mathrm{mmol} / \mathrm{l} \mathrm{EDTA}, 10 \mathrm{mmol} / \mathrm{l}$ sodium vanadate, and $2 \mathrm{mmol} / \mathrm{l}$ PMSF) and centrifuged at $15,000 \times g$ at $4^{\circ} \mathrm{C}$ for $20 \mathrm{~min}$. After protein measurement, $70 \mu \mathrm{g}$ of protein were separated by SDS-PAGE on $10 \%$ polyacrylamide gels. Proteins were then transferred to nitrocellulose membranes at $120 \mathrm{~V}$ for $2 \mathrm{~h}$. Non-specific binding to nitrocellulose was reduced by preincubating the filter in blocking buffer ( $5 \% \mathrm{BSA}, 10 \mathrm{mmol} / \mathrm{l}$ Tris, $150 \mathrm{mmol} / \mathrm{l} \mathrm{NaCl}$, and $0.02 \%$ Tween 20 ) overnight at $4^{\circ} \mathrm{C}$. The nitrocellulose membranes were then incubated for $4 \mathrm{~h}$ at $22^{\circ} \mathrm{C}$ with anti-Bcl-2, anti-Bax $\alpha$, or anti-Bcl-xl antibodies in incubating buffer (3\% BSA, $10 \mathrm{mmol} / \mathrm{l}$ Tris, $150 \mathrm{mmol} / \mathrm{l} \mathrm{NaCl}$, and $0.02 \%$ Tween 20 ). The blots were subsequently incubated with $150 \mathrm{ng} / \mathrm{ml}$ of secondary antibody HRP conjugated (Zymed, San Francisco, USA) for $2 \mathrm{~h}$ at $22^{\circ} \mathrm{C}$. Finally, the blots were incubated in SuperSignal solution (Pierce, Boston, USA) and exposed to autoradiography film (Kodak, São Paulo, Brazil).

Table 2. Effects of dexamethasone treatment on lipids, insulin and glucose plasma levels

\begin{tabular}{llc}
\hline & Control & DEX \\
\hline FFA (mg/dl) & $96.3 \pm 7.3$ & $187.6 \pm 8.7^{*}$ \\
Triglycerides $(\mathrm{mg} / \mathrm{dl})$ & $76.5 \pm 8.5$ & $116.1 \pm 13.5^{*}$ \\
Cholesterol $(\mathrm{mg} / \mathrm{dl})$ & $80.5 \pm 3.7$ & $78.4 \pm 7.1$ \\
Insulin $(\mathrm{ng} / \mathrm{ml})$ & $0.14 \pm 0.20$ & $2.1 \pm 0.4^{*}$ \\
Glucose $(\mathrm{mg} / \mathrm{dl})$ & $69.3 \pm 1.7$ & $137.3 \pm 8.8^{*}$ \\
\hline
\end{tabular}

Values are means \pm SEM. ${ }^{*}$ significantly different DEX $v s$. Control group $(n=9) .{ }^{*} p<0.05$, with $p$ values calculated from $t$ test on the average difference between Control and DEX. FFA, free fatty acids.
Band intensities were measured by digital scanning followed by quantification using Scion Image analysis software (Scion Corp. Frederick, MD, USA).

\section{MTS cell viability assay}

In all sets of experiments, the viability of the cells was determined after $3 \mathrm{~h}$ incubation period using a microplate-based MTS kinetic assay, following the instructions contained in the manual (CellTiter 96 Non-Radioactive Cell Proliferation Assays, Promega Corporation, Madison, WI).

\section{Determination of intracellular $\mathrm{ROS}$ by $\mathrm{H}_{2} \mathrm{DCFH}-\mathrm{DA}$ fluorescence}

Islets from control and dexamethasone-treated animals were isolated as described before and incubated for $45 \mathrm{~min}$ in KrebsHepes buffer containing $5.6 \mathrm{mmol} / \mathrm{l}$ of glucose. Thereafter islets were placed in black coloured Costar plates and incubated in Krebs-Hepes buffer containing $25 \mathrm{mmol} / \mathrm{l}$ of glucose and 10 $\mu \mathrm{mol} / \mathrm{l}$ of DCFH-DA (2',7'-dichlorfluorescein-diacetate) for 30 $\mathrm{min}$ at $37^{\circ} \mathrm{C}$. Fluorescence emission from DCF was detected at $460 / 530 \mathrm{~nm}$ excitation/emission using a fluorometer (Fusion, PerkinElmer Life Science, USA). Protein concentration was measured by Bradford. The resulting fluorescence was expressed as $\Delta \mathrm{UF}$ normalized to $\mu \mathrm{g} / \mathrm{ml}$ of protein.

\section{Statistical analysis}

The results were expressed as mean \pm SEM for the indicated number of experiments $(n)$. Statistical comparisons were made using unpaired Student's $t$-test or ANOVA followed by the Bonferroni's post-test when appropriate. $p<0.05$ was considered statistically significant.

\section{Results}

Effects of dexamethasone treatment on lipids, insulin and glucose plasma levels

Table 2 shows the mean values for insulin, glucose, triglycerides and free fatty acid (FFA) levels in the plasma of fasted rats. Dexamethasone-treated animals (DEX) demonstrated a significant increase in all biochemical parameters compared to control group $(n=9, p<0.05)$ except for the cholesterol plasma levels that were similar between groups after the dexamethasone treatment.

\section{Effects of dexamethasone treatment on insulin release}

Figure 1 shows the amount of insulin secreted normalized to the total protein content in the islets. At a non-stimulatory 
concentration of glucose $(2.8 \mathrm{mM})$, there were no differences between DEX and control group $(n=6)$. Using a glucose concentration that matched post-prandial levels in vivo $(8.3$ $\mathrm{mmol} / \mathrm{l})$, the insulin secretion was significantly higher in DEX compared to control islets $(17.98 \pm 1.6$ and $8.85 \pm 1.5 \mathrm{ng} / \mathrm{ml} / \mu \mathrm{g}$ protein, respectively). Finally, at supra-stimulatory concentrations ( $22 \mathrm{mmol} / \mathrm{l}$ glucose), the insulin secretion in DEX was also significantly higher than in control islets $(68.8 \pm 6.5$ and $47.8 \pm 6.2 \mathrm{ng} / \mathrm{ml} / \mu \mathrm{g}$ protein, respectively, $p<0.05)$.

\section{c-DNA array screening}

Out of the 1176 genes represented in the cDNA array membrane, 60 were up-regulated and 28 down-regulated in islets from dexamethasone-treated rats. A complete list of all dexamethasone-modulated genes is given in Table 3. Interestingly, islets from dexamethasone-treated animals showed up-regulation of several pro-apoptotic genes, including Bax a and JNK, oncogenes like H-Ras a, Ras p 21 protein activator and growth factors: fibroblast growth factors, like fibroblast,
TGF- $\beta$. Among the down-regulated genes are those involved in antioxidant response (gluthathione peroxidase 4) proliferation pathways (MAPKK1, fibroblast growth factor 10) and heat-shock proteins.

\section{RT-PCR and Western blotting analysis}

RT-PCR analysis showed that Bax $\alpha$, Fas and JNK genes expression was higher in DEX islets compared with control islets (1.95-, 1.5- and 1.65-fold, respectively; $p<0.05, n=6$ ) (Fig. 2). Dexamethasone treatment did not alter the Bcl-2, Bcl-xl and Bad gene expression. Western-blotting analysis indicated that the expression of pro-apoptotic Bax a protein was increased (2.3-fold) whereas the anti-apoptotic protein Bcl-2 was decreased (1.5-fold) after dexamethasone treatment, when compared to control. No differences in the expression of Bcl-xl were noticed after GC exposure (Fig. 3). Although no differences in $\mathrm{Bcl}-2$ gene expression were observed, $\mathrm{Bcl}-2$ protein expression was 1.5-fold lower in islets from dexamethasone-treated rats compared with control islets $(p<0.05, n=4)$.
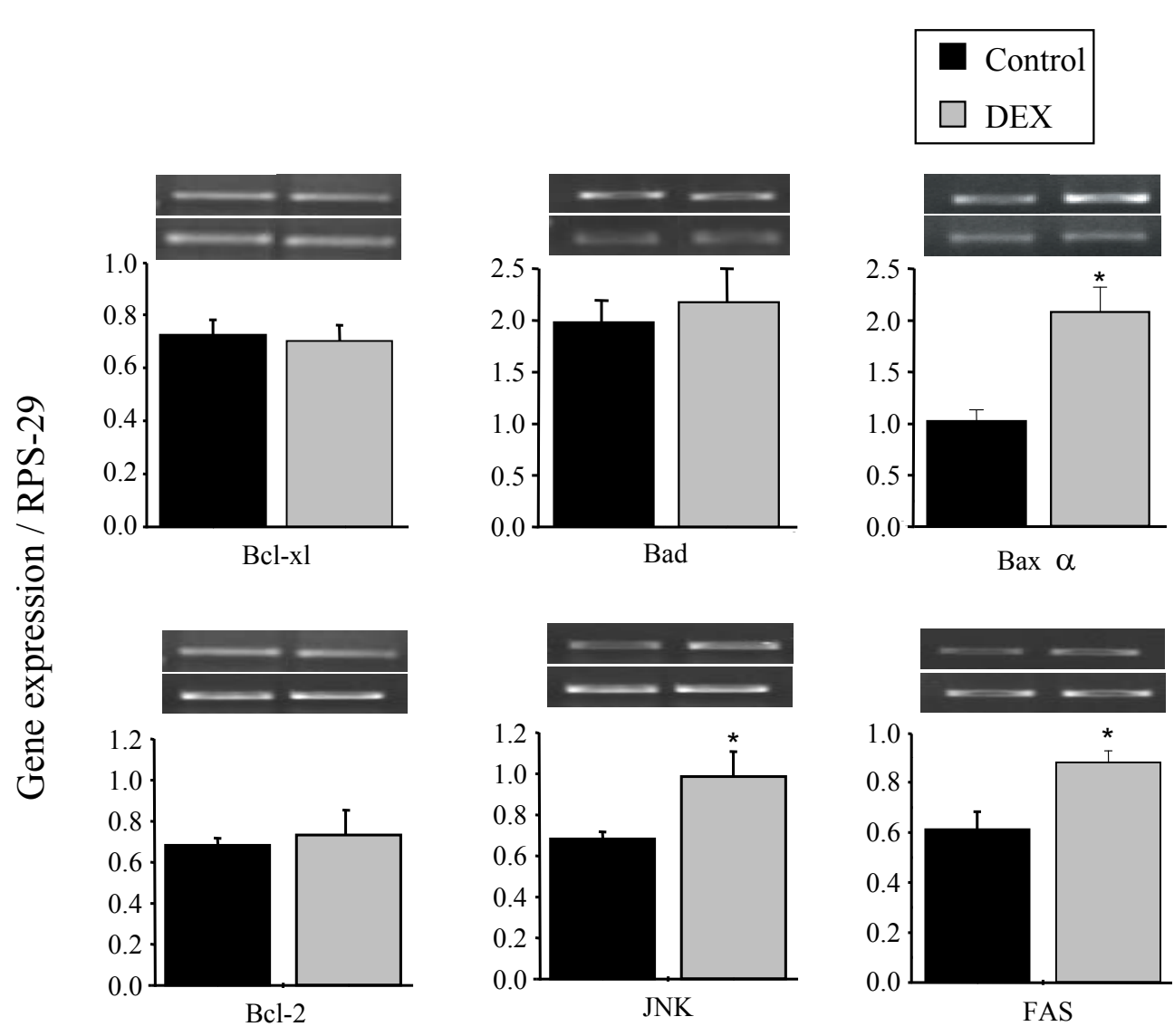

Figure 2. Confirmation by RT-PCR of 6 selected genes that were significantly up- or down-regulated in pancreatic islets after dexamethasone treatment. The bars represent the means \pm SEM of 6 experiments performed with specific primer sets (Table 1) and normalized against the ribosomal protein S29 (RPS-29). ${ }^{*} p<0.05$, with $p$ values calculated from $t$ test on the average difference between control and dexamethasone group (DEX). 
Effects of dexamethasone treatment on mitochondrial activity

Islet-cells from DEX rats showed a decrease of $23.35 \%$ mitochondrial $\mathrm{NAD}(\mathrm{P}) \mathrm{H}$ formation compared to controls, as measured by the MTS assays $(n=3, p<0.05)$. The results were normalized to total protein content and indicated as percentage of control islets.

\section{Effects of dexamethasone on ROS production}

Experiments using $\mathrm{H}_{2}$ DCF-DA fluorescence as an indicator of oxidative stress showed that dexamethasone induce small increase (19\%) in total reactive oxygen species in islets from rats treated with dexamethasone for 5 days $(n=$ $8, p<0.05)$.

Table 3. Changes in pancreatic islet-related mRNA modulation by dexamethasone treatment

\begin{tabular}{|c|c|c|}
\hline Gene name & GenBank accession & Fold modulation \\
\hline \multicolumn{3}{|l|}{ Up-regulated genes } \\
\hline Neuropeptide Y & M20373 & 15.20 \\
\hline Cytochrome P450 IIA1 (hepatic steroid hydroxylase IIA1) gene & J02669 & 11.30 \\
\hline Clusterin & M64723 & 8.48 \\
\hline Interleukin 13 & L26913 & 7.05 \\
\hline Fibroblast growth factor receptor 1 & D12498 & 6.90 \\
\hline trk precursor & M85214 & 6.37 \\
\hline GAP-associated protein (p190). & M94721 & 5.04 \\
\hline p21, cdk interacting ptn 1 & L41275 & 5.02 \\
\hline Thyroid hormone receptor ErbA- $\beta-2$, pituitary specific & M25071 & 4.95 \\
\hline Secretogranin III & U02983 & 4.94 \\
\hline Arginine vasopressin receptor $1 \mathrm{~B}$ & D45400 & 4.63 \\
\hline Cytochrome P450, subfamily IIC (mephenytoin 4-hydroxylase) & J02657 & 4.38 \\
\hline Interleukin 7 & AF010464 & 4.24 \\
\hline Transforming growth factor beta (TGF- $\beta$ ) & M55431 & 4.08 \\
\hline Somatostatin receptor 4 & U04738 & 4.05 \\
\hline Colony stimulating factor 1 receptor & X61479 & 4.00 \\
\hline Insulin-like growth factor binding protein 1 & M89791 & 3.99 \\
\hline Adrenergic receptor, a 1a & U13368 & 3.98 \\
\hline Phospholipase A2, group 2C & U07798 & 3.82 \\
\hline Complement component 5 , receptor 1 & AB003042 & 3.69 \\
\hline Parathyroid hormone receptor & L19475 & 3.67 \\
\hline Bax- $\alpha$ & U49729 & 3.50 \\
\hline Endothelin 1 & M64711 & 3.48 \\
\hline Phosphatidate phosphohydrolase type $2 \mathrm{a}$ & U90556 & 3.42 \\
\hline Interleukin $1 \beta$ & M98820 & 3.33 \\
\hline ATPase, $\mathrm{Na}+\mathrm{K}+$ transporting, $\alpha \mathrm{1}$ & M28647 & 3.25 \\
\hline ATP synthase, $\mathrm{H}+$ transporting, mitochondrial F0 complex, subunit c & D13123 & 3.21 \\
\hline Apolipoprotein D & X55572 & 3.21 \\
\hline Calcineurin & L03554 & 3.16 \\
\hline Transforming growth factor, $\beta 1$ & X52498 & 3.13 \\
\hline Solute carrier family 25 (mitochondrial carrier; adenine nucleotide translocator) & D12771 & 3.08 \\
\hline c-jun Nh2-terminal kinase 1, JNK-1- mapk8 & L27129 & 3.02 \\
\hline Interleukin 18 & U77776 & 2.99 \\
\hline Platelet-derived growth factor receptor, $\beta$ & Z14119 & 2.98 \\
\hline Inositol 1, 4, 5-triphosphate receptor 3 & L06096 & 2.97 \\
\hline ATPase, $\mathrm{Ca}++$ transporting, plasma membrane 2 & J03754 & 2.93 \\
\hline Cytochrome P450 4F6 & U39208 & 2.87 \\
\hline Pancreatic polypeptide receptor 1 & U42388 & 2.77 \\
\hline Insulin receptor-related receptor & M90661 & 2.77 \\
\hline Cathepsin L & Y00697 & 2.73 \\
\hline
\end{tabular}


Table 3. Continued

\begin{tabular}{|c|c|c|}
\hline Gene name & GenBank accession & Fold modulation \\
\hline Interferon $\gamma$-induced protein 10 & U17035 & 2.73 \\
\hline $\mathrm{N}$-ras proto-oncogene, transforming protein $\mathrm{p} 21$ & X68394 & 2.66 \\
\hline ATP synthase, $\mathrm{H}+$ transporting, mitochondrial F0 complex, subunit $b$, & M35052 & 2.65 \\
\hline Arrestin-D & U03629 & 2.59 \\
\hline Cytokine-induced neutrophil chemoattractant-2 & D21095 & 2.55 \\
\hline v-crk proto-oncogene & D44481 & 2.49 \\
\hline Arachidonate 12-lipoxygenase & L06040 & 2.46 \\
\hline Low-density lipoprotein receptor & $\mathrm{X} 13722$ & 2.43 \\
\hline Adrenergic receptor kinase, $\beta 2$ & M87855 & 2.39 \\
\hline Platelet-derived growth factor & Z14117 & 2.29 \\
\hline Protein tyrosine phosphatase $2 \mathrm{E}$ & U18293 & 2.27 \\
\hline Protein tyrosine phosphatase $4 \mathrm{a} 1$ & L27843 & 2.20 \\
\hline Granzyme M & L05175 & 2.16 \\
\hline Protein convertase 1 , prohormone convertase 1 & M76705 & 2.13 \\
\hline cAMP-specific 3,5-cyclic phosphodiesterase 4C & M25347 & 2.01 \\
\hline v-crk-associated tyrosine kinase substrate & D29766 & 2.01 \\
\hline H-ras proto-oncogene; transforming protein $\mathrm{p} 21$ & M13011 & 2.00 \\
\hline RAS p 21 protein activator 1 & L13151 & 2.00 \\
\hline Arrestin, $\beta 1$ & M91589 & 2.00 \\
\hline Adenosine A1 receptor & M64299 & 2.00 \\
\hline Adenosine $\mathrm{A} 2 \mathrm{~B}$ receptor & M91466 & 2.00 \\
\hline \multicolumn{3}{|l|}{ Down-regulated genes } \\
\hline Glutathione peroxidase 4 & X82679 & 0.48 \\
\hline Inhibitor of DNA binding 1, helix-loop-helix protein (splice variation) & D10862 & 0.47 \\
\hline Interleukin 8 receptor, $\beta$ & X77797 & 0.47 \\
\hline Colony stimulating factor 3 & U37101 & 0.43 \\
\hline Heat shock $90-\mathrm{kDa}$ protein $\beta$ (HSP90- $\beta$ ); HSP84; HSPCB & S45392 & 0.40 \\
\hline Mitogen activated protein kinase kinase 1 & Z16415 & 0.38 \\
\hline Glutathione peroxidase 5 & X62404 & 0.37 \\
\hline beta-nerve growth factor precursor ( $\beta$-NGF) & M36589 & 0.37 \\
\hline Cadherin 22 & D83349 & 0.36 \\
\hline Heat shock $70 \mathrm{kD}$ protein 5 & M14050 & 0.36 \\
\hline Cyclin D1 & AF148946 & 0.35 \\
\hline Jun D proto-oncogene & D26307 & 0.33 \\
\hline CXC chemokine LIX & U90448 & 0.33 \\
\hline Glucagon receptor & L04796 & 0.31 \\
\hline Cholinergic receptor, nicotinic, alpha polypeptide 4 & L31620 & 0.30 \\
\hline ERK2, mitogen-activated protein kinase 1 & M64300 & 0.30 \\
\hline Glutathione synthetase & L38615 & 0.28 \\
\hline Cholinergic receptor, nicotinic, $\beta$ polypeptide 2 & L31622 & 0.28 \\
\hline ATP receptor, $\mathrm{P} 2 \mathrm{X}$ purinoceptor 1 & X80477 & 0.27 \\
\hline Fibroblast growth factor 10 & D79215 & 0.27 \\
\hline Glutathione reductase & U73174 & 0.20 \\
\hline Cytochrome c oxidase, subunit Va & $\mathrm{X} 15030$ & 0.18 \\
\hline Integrin, $\beta 4$ & U60096 & 0.17 \\
\hline Heat shock $70 \mathrm{kD}$ protein $1 \mathrm{~A}$ & Z27118 & 0.12 \\
\hline Corticotrophin releasing hormone receptor 2 & U16253 & 0.12 \\
\hline Transcription factor AP-1 & $\mathrm{X} 17163$ & 0.11 \\
\hline Glucose-6-phosphate dehydrogenase & X07467 & 0.10 \\
\hline Cadherin 6 & D25290 & 0.08 \\
\hline
\end{tabular}

Genes were screening using the Atlas Rat 1.2 Array. Values represent -fold modulation, as compared to expression in control islets. $n=3$ independent experiments. 


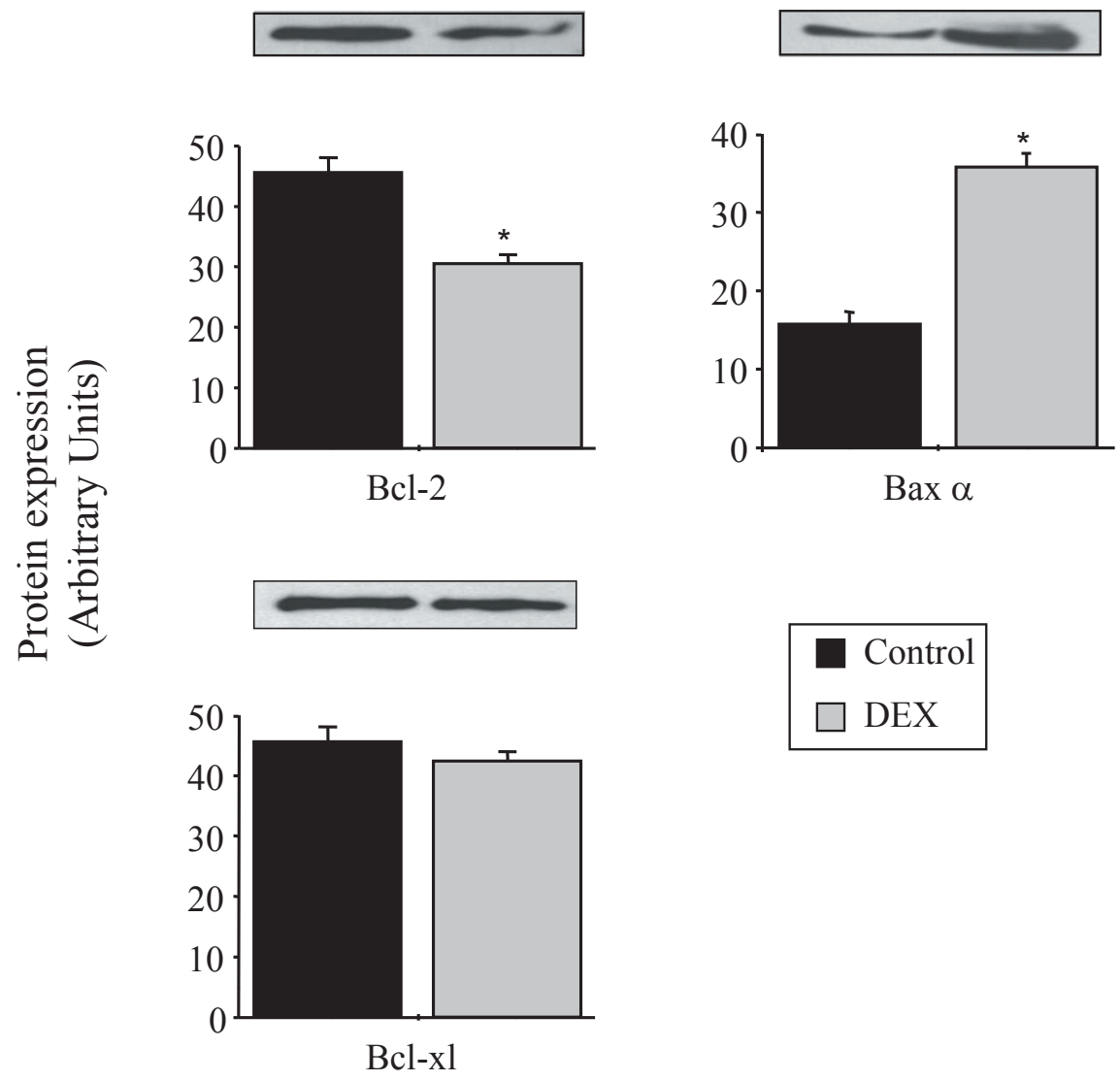

Figure 3. Protein expression of three transcripts to validate the cDNA array analysis. The islet proteins were extracted (see Materials and Methods) and equal amounts of protein from control and dexamethasone-treated (DEX) islets were resolved by SDS-PAGE on 10\% gels and transferred to a nitrocellulose membrane. The proteins were identified with anti-Bax $\alpha$, anti-Bcl-2, and anti-Bcl-xl antibodies. The values are the means \pm SEM of 4 experiments. ${ }^{\star} p<0.05$ for control $v s$. DEX islets.

\section{Discussion}

GCs administration has been used experimentally as a model of insulin resistance. In this work, we used an in vivo model were the deleterious effects of GC on insulin secretion and apoptosis were still compensate by other factors such as hyperglycemia, hyperinsulinemia and hyperlipidemia (Rafacho et al. 2007, 2009). The objectives were to indentify the early changes in gene and protein expression that could lead to $\beta$-cell failure and diabetes after long-term exposure to GC.

When in excess, GCs can induce hyperglycemia and type 2 diabetes (Lenzen and Bailey 1984; Ranta et al. 2006). Dexamethasone also induces hyperlipidemia, which is associated with the increased insulin and glucose levels (Nicod et al. 2003). Increases in triglycerides, FFA, glucose and insulin plasma levels (Table 1) definitely contribute to the cellular dysfunctions that lead to diabetes. The high insulin blood levels in dexamethasone-treated animals are probably an adaptation of pancreatic $\beta$-cell to the insulin resistance caused by the steroid in liver, muscle, adipose tissues and in addition to increased rates of gluconeogenesis (Lenzen and Bailey 1984; Nicod et al. 2003). These characteristics (high level of insulin and glucose in plasma) are typical features of the type 2 diabetes, showing that dexamethasone treatment may be an interesting animal model for studying several factors at the onset of type 2 diabetes.

Whether in vivo or in vitro, GCs can either decrease or increase insulin release, depending on the dose and period of exposure (Jeong et al. 2001). Several studies suggest an inhibitory effect of in vitro administration of dexamethasone on insulin release from pancreatic islets (Barseghian and Levine 1980; Pierluissi et al. 1986; Lambillotte et al. 1997; Jeong et al. 2001). On the other hand, a clear increase in potassium- and glucose-stimulated insulin secretion from isolated pancreatic islets is observed after in vivo administration of dexamethasone to rats (Rafacho et al. 2009) (Fig. 1). These data are in accordance with previous studies using similar approaches (Kawai and Kuzuya 1977; Brunstedt and Nielsen 1981) and with clinical observations in patients (Cushing's syndrome) with high levels of GC (Schafroth et 


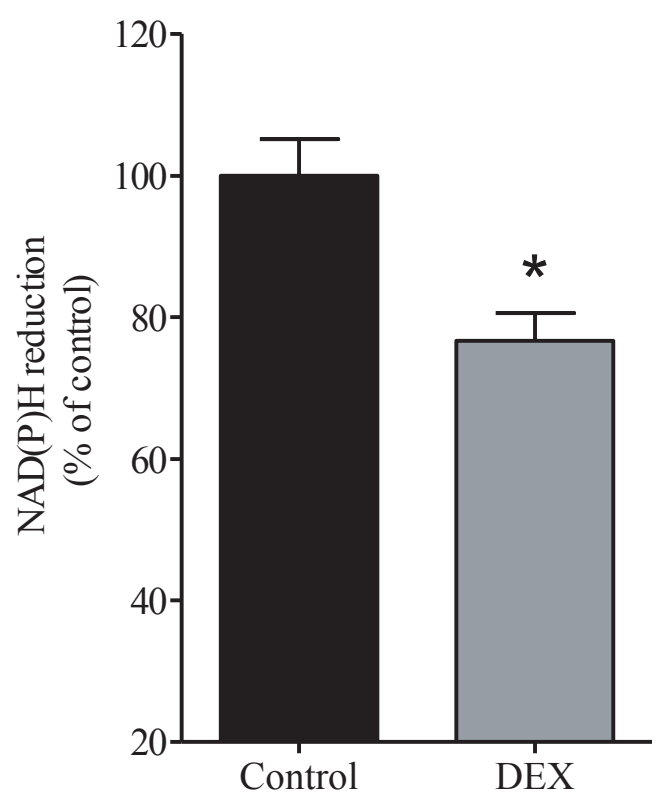

Figure 4. Rats were treated with dexamethasone $(1 \mathrm{mg} / \mathrm{kg} /$ day $)$ during 5 days. Groups of 100 islets were collected for each group and MTS experiments were performed according to instructions. Dexamethasone decreases $\mathrm{NAD}(\mathrm{P}) \mathrm{H}$ reduction as showed in Figure 4 . The values are the means \pm SEM of 3 experiments, normalized by control values . ${ }^{\star} p<0.05$ for control $v s$. DEX islets. DEX, dexamethasone group.

al. 2000). The rat islets used in our study for the 1 -h culture had been preconditioned to the 5-day in vivo dexamethasone treatment, which might cause a compensatory insulin release in response to increased insulin resistance and elevated glucose production by the liver. The hyper-triglyceridemia may be a consequence of an increase hepatic production and secretion of very low density lipoprotein, and/or a direct effect on enzymes involved with triglyceride catabolism, leading to the impairment of lipoprotein lipase activity in adipose tissue (Cole et al. 1982). These changes, in the long term, may permanently damage the $\beta$-cell. An indicative of this harm is the impairment in $\mathrm{NAD}(\mathrm{P}) \mathrm{H}$ reduction rate in islets from dexamethasone-treated rats (Fig. 4). In view of the fact that $\beta$-cells are essentially a sensor for metabolic energy changes, a decrease in $\mathrm{NAD}(\mathrm{P}) \mathrm{H}$ production may indicate an impairment of mitochondrial activity and loss of viability of these cells.

The apoptosis in type 2 diabetes has been the matter of recent studies aiming to decipher the molecular mechanisms that leads to $\beta$-cell failure (Porte and Kahn 2001; Ranta et al. 2006). The decrease in $\beta$-cell mass is possibly a result of an increase in apoptosis rather than a decrease in proliferation (Pick et al. 1998), and apoptosis may therefore be one of the causes of the type 2 diabetes progression. The $\beta$-cell undergoes apoptosis when exposed to dexamethasone in

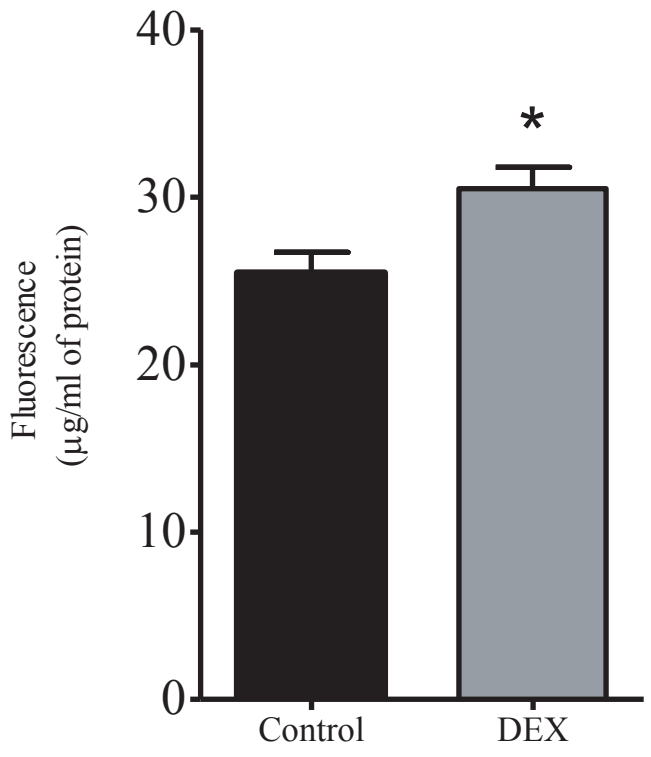

Figure 5. Reactive oxygen species were measured by $\mathrm{H}_{2}$ DCF-DA fluorescence. After isolation, islet from dexamethasone-treated rats and control animals were incubated for 45 minutes in Kreb's solution and for 30 minutes with $\mathrm{H}_{2}$ DCF-DA as described in Materials and Methods. The values are the means \pm SEM of 4 experiments performed in duplicate. ${ }^{*} p<0.05$ for control $v$ s. DEX islets. DEX, dexamethasone group.

vitro (Weinhaus et al. 2000; Ranta et al. 2006; Roma et al. 2009). Reactive oxygen species are involved in dexamethasone-induced apoptosis and either catalase overexpression or antioxidant treatment ( $\mathrm{N}$-acetyl-L-cysteine) can counteract in vitro GC effects in pancreatic cell lines and islets, respectively (Roma et al. 2009, 2011). On the other hand, in vivo GC treatment leads to increase in $\beta$-cell mass. Proliferation may be due to increase proliferation rate of $\beta$-cell and ductal cells (Jorns et al. 2010) and might be triggered by high glucose and/or insulin levels (Rafacho et al. 2009). In animals treated with hydrocortisone $(25 \mathrm{mg} / \mathrm{kg} /$ day $)$ for 5 days, apoptosis and proliferation are present (Jorns et al. 2010). Here we showed that even in a situation where proliferation has shown to prevail over apoptosis (dexamethasone $1 \mathrm{mg} /$ $\mathrm{kg}$ /day during 5 days) mitochondrial apoptotic pathway is early modulated by the GC and can contribute to the further decompensation and $\beta$-cell death. The mitochondrial dysfunction might result from oxidative stress induced by dexamethasone (Fig. 5) (Roma et al. 2009, 2011) or by other deleterious effects from elevated levels of glucose and lipids (El-Assaad et al. 2010).

The modulation of gene and protein expression in pancreatic islets by dexamethasone treatment is only partially understood. Interestingly, Bax $\alpha$, an important pro-apoptotic protein, is up-regulated in pancreatic islets by in vivo 
dexamethasone treatment (Fig. 3). There is already concrete evidences supporting a role for Bax $\alpha$ in the induction of apoptosis in pancreatic islets (Oltvai et al. 1993; Mizuno et al. 1998) and other cell types (Schmidt et al. 2004). Additionally to the genes that might directly act in apoptosis by the mitochondrial pathway, we found several other genes of interest in pancreatic islets from rats exposed to dexamethasone, which directly and/or indirectly mediates GC effects on beta cell. Some of these genes are stress response like JNK, which is one of the hallmarks of oxidative stress and JNK signaling activation leads to apoptosis and impaired insulin secretion (Kaneto et al. 2005). We also observed up-regulation of some growth factors and oncogenes, in agreement with previous results where proliferation pathways are activated and lead to increase proliferation rates in this model (Rafacho et al. 2009). On the other hand, mRNA expression of antioxidant proteins were down-regulated, indicating the possible link between these early changes in gene expression and the involvement of oxidative stress in late alterations of $\beta$-cell function and survival. Indeed, GCs can modulate these pathways in many cell types such as lymphoid cells (Schmidt et al. 2004), NIH-373 fibroblast cells (Kassel et al. 2001), chondrocytes (Chrysis et al. 2005), pancreatic islet-cells (Weinhaus et al. 2000; Ranta et al. 2006) and others. Nevertheless, more experiments are necessary for the better understanding of the role of all these genes in cellular protection and apoptosis after GC exposure. These data need to be extended to measurements of protein expression and phosphorylation and reporter genes in dependence upon exposure to GC.

In conclusion, our results show that dexamethasone modulates the expression of several genes in pancreatic islets. The deleterious effects of dexamethasone on $\beta$-cell possibly involve the production of ROS and modulation of mitochondrial pathway, principally the $\mathrm{Bcl}-2$ proteins. This may contribute to the shift from proliferation observed in the early stages of GC treatment, to apoptosis after longterm exposure to GC and ultimately GC-induced type 2 diabetes.

Acknowledgments. This work was supported by Fundação de Amparo à Pesquisa do Estado de São Paulo (FAPESP), grants No. 04/14494-6, and Conselho Nacional de Desenvolvimento Científico e Tecnológico (CNPq). LP Roma was holder of a CAPES research fellowship.

\section{References}

Adams J. M., Cory S. (2001): Life-or-death decisions by the Bcl-2 protein family. Trends Biochem. Sci. 26, 61-66 http://dx.doi.org/10.1016/S0968-0004(00)01740-0

Auphan N., DiDonato J. A., Rosette C., Helmberg A., Karin M. (1995): Immunosuppression by glucocorticoids: inhibition of
NF-kappa B activity through induction of I kappa B synthesis. Science 270, 286-290 http://dx.doi.org/10.1126/science.270.5234.286

Barseghian G., Levine R. (1980): Effect of corticosterone on insulin and glucagon secretion by the isolated perfused rat pancreas. Endocrinology 106, 547-552 http://dx.doi.org/10.1210/endo-106-2-547

Beato M. (1991): Transcriptional control by nuclear receptors. FASEB. J. 5, 2044-2051

Beato M., Herrlich P., Schutz G. (1995): Steroid hormone receptors: many actors in search of a plot. Cell 83, 851-857 http://dx.doi.org/10.1016/0092-8674(95)90201-5

Brunstedt J., Nielsen J. H. (1981): Direct long-term effect of hydrocortisone on insulin and glucagon release from mouse pancreatic islets in tissue culture. Acta Endocrinol. (Copenh.) 96, 498-504

Chrysis D., Zaman F., Chagin A. S., Takigawa M., Savendahl L. (2005): Dexamethasone induces apoptosis in proliferative chondrocytes through activation of caspases and suppression of the Akt-phosphatidylinositol 3'-kinase signaling pathway. Endocrinology 146,1391-1397 http://dx.doi.org/10.1210/en.2004-1152

Cole T. G., Wilcox H. G., Heimberg, M. (1982): Effects of adrenalectomy and dexamethasone on hepatic lipid metabolism. J. Lipid. Res. 23, 81-91

Cory S., Adams J. M. (2002): The Bcl2 family: regulators of the cellular life-or-death switch. Nat. Rev. Cancer 2, 647-656 http://dx.doi.org/10.1038/nrc883

Delaunay F., A. Khan, Cintra A., Davani B., Ling Z. C., Andersson A., Ostenson C. G., Gustafsson J., Efendic S., Okret S. (1997): Pancreatic beta cells are important targets for the diabetogenic effects of glucocorticoids. J. Clin. Invest. 100, 2094-2098 http://dx.doi.org/10.1172/JCI119743

Eizirik D. L., Mandrup-Poulsen T. (2001): A choice of death--the signal-transduction of immune-mediated beta-cell apoptosis. Diabetologia 44, 2115-2133 http://dx.doi.org/10.1007/s001250100021

El-Assaad W., Joly E., Barbeau A., Sladek R., Buteau J., Maestre I., Pepin E., Zhao S., Iglesias J., Roche E., Prentki M. (2010): Glucolipotoxicity alters lipid partitioning and causes mitochondrial dysfunction, cholesterol, and ceramide deposition and reactive oxygen species production in INS832/13 ss-cells. Endocrinology 151, 3061-3073 http://dx.doi.org/10.1210/en.2009-1238

Fischer B., Rausch U., Wollny P., Westphal H., Seitz J., Aumuller G. (1990): Immunohistochemical localization of the glucocorticoid receptor in pancreatic beta-cells of the rat. Endocrinology 126, 2635-2641

http://dx.doi.org/10.1210/endo-126-5-2635

Hoogwerf B., Danese R. D. (1999): Drug selection and the management of corticosteroid-related diabetes mellitus. Rheum. Dis. Clin. North. Am. 25, 489-505 http://dx.doi.org/10.1016/S0889-857X(05)70083-1

Jeong I. K., Oh S. H., Kim B. J., Chung J. H., Min Y. K., Lee M. S., Lee M. K., Kim K. W. (2001): The effects of dexamethasone on insulin release and biosynthesis are dependent on the dose and duration of treatment. Diabetes Res. Clin. Pract. 51, 163-171 http://dx.doi.org/10.1016/S0168-8227(00)00229-1 
Jorns A., Sennholz C., Naujok O., Lenzen S. (2010): Beta cell mass regulation in the rat pancreas through glucocorticoids and thyroid hormones. Pancreas 39, 1167-1172 http://dx.doi.org/10.1097/MPA.0b013e3181dfce4f

Kaneto H., Matsuoka T. A., Nakatani Y., Kawamori D., Matsuhisa M., Yamasaki Y. (2005): Oxidative stress and the JNK pathway in diabetes. Curr. Diabetes Rev. 1, 65-72 http://dx.doi.org/10.2174/1573399052952613

Kassel O., Sancono A., Kratzschmar J., Kreft B., Stassen M., Cato A. C. (2001): Glucocorticoids inhibit MAP kinase via increased expression and decreased degradation of MKP-1. EMBO J. 20, 7108-7116 http://dx.doi.org/10.1093/emboj/20.24.7108

Kaufmann S. H., Hengartner M. O. (2001): Programmed cell death: alive and well in the new millennium. Trends Cell. Biol. 11, 526-534 http://dx.doi.org/10.1016/S0962-8924(01)02173-0

Kawai A., Kuzuya N. (1977): On the role of glucocorticoid in glucose-induced insulin secretion. Horm. Metab. Res. 9, 361-365 http://dx.doi.org/10.1055/s-0028-1093528

Kutlu B., Cardozo A. K., Darville M., I.Kruhoffer M., Magnusson N., Orntoft T., Eizirik D. L. (2003): Discovery of gene networks regulating cytokine-induced dysfunction and apoptosis in insulin-producing INS-1 cells. Diabetes 52, 2701-2719 http://dx.doi.org/10.2337/diabetes.52.11.2701

Lambillotte C., Gilon P., Henquin J. C. (1997): Direct glucocorticoid inhibition of insulin secretion. An in vitro study of dexamethasone effects in mouse islets. J. Clin. Invest. 99, $414-423$ http://dx.doi.org/10.1172/JCI119175

Lenzen S., Bailey C. J. (1984): Thyroid hormones, gonadal and adrenocortical steroids and the function of the islets of Langerhans. Endocr. Rev. 5, 411-434 http://dx.doi.org/10.1210/edrv-5-3-411

Mizuno N., Yoshitomi H., Ishida H., Kuromi H., Kawaki J., Seino Y., Seino S. (1998): Altered bcl-2 and bax expression and intracellular Ca2+ signaling in apoptosis of pancreatic cells and the impairment of glucose-induced insulin secretion. Endocrinology 139, 1429-1439 http://dx.doi.org/10.1210/en.139.3.1429

Nicod N., Giusti V., Besse C., Tappy L. (2003): Metabolic adaptations to dexamethasone-induced insulin resistance in healthy volunteers. Obes. Res. 11, 625-631 http://dx.doi.org/10.1038/oby.2003.90

Oltvai Z. N., Milliman C. L., Korsmeyer S. J. (1993): Bcl-2 heterodimerizes in vivo with a conserved homolog, Bax, that accelerates programmed cell death. Cell 74, 609-619 http://dx.doi.org/10.1016/0092-8674(93)90509-O

Patel J. V., Cummings D. E., Girod J. P., Mascarenhas A.V., Hughes E. A., Gupta M., Lip G. Y., Reddy S., Brotman D. J. (2006): Role of metabolically active hormones in the insulin resistance associated with short-term glucocorticoid treatment. J. Negat. Results Biomed. 5, 14 http://dx.doi.org/10.1186/1477-5751-5-14

Pick A., Clark J., Kubstrup C., Levisetti M., Pugh W., BonnerWeir S., Polonsky K. S. (1998): Role of apoptosis in failure of beta-cell mass compensation for insulin resistance and beta-cell defects in the male Zucker diabetic fatty rat. Diabetes 47, 358-364

http://dx.doi.org/10.2337/diabetes.47.3.358

Pierluissi J., Navas F. O., Ashcroft S. J. (1986): Effect of adrenal steroids on insulin release from cultured rat islets of Langerhans. Diabetologia 29, 119-121 http://dx.doi.org/10.1007/BF00456122

Porte D. Jr., Kahn S. E. (2001): beta-cell dysfunction and failure in type 2 diabetes: potential mechanisms. Diabetes $\mathbf{5 0}$ (Suppl. 1), S160-163 http://dx.doi.org/10.2337/diabetes.50.2007.S160

Rafacho A., Roma L. P., Taboga S. R., Boschero A. C., Bosqueiro J. R. (2007): Dexamethasone-induced insulin resistance is associated with increased connexin $36 \mathrm{mRNA}$ and protein expression in pancreatic rat islets. Can. J. Physiol. Pharmacol. 85, 536-545 http://dx.doi.org/10.1139/Y07-037

Rafacho A., Cestari T. M., Taboga S. R., Boschero A. C., Bosqueiro J. R. (2009): High doses of dexamethasone induce increased beta-cell proliferation in pancreatic rat islets. Am. J. Physiol. Endocrinol. Metab. 296, E681-689 http://dx.doi.org/10.1152/ajpendo.90931.2008

Ranta F., Avram D., Berchtold S., Dufer M., Drews G., Lang F., Ullrich S. (2006): Dexamethasone induces cell death in insulin-secreting cells, an effect reversed by exendin-4. Diabetes 55, 1380-1390 http://dx.doi.org/10.2337/db05-1220

Roma L. P., Bosqueiro J. R., Cunha D. A., Carneiro E. M., GurgulConvey E., Lenzen S., Boschero A. C., Souza K. L. (2009): Protection of insulin-producing cells against toxicity of dexamethasone by catalase overexpression. Free Radic. Biol. Med. 47, 1386-1393 http://dx.doi.org/10.1016/j.freeradbiomed.2009.08.010

Roma L. P., Oliveira C. A., Carneiro E. M., Albuquerque G. G., Boschero A. C., Souza K. L. (2011): N-acetylcysteine protects pancreatic islet against glucocorticoid toxicity. Redox. Rep. 16, 173-180 http://dx.doi.org/10.1179/1351000211Y.0000000006

Schaaf M. J., Cidlowski J. A. (2002): Molecular mechanisms of glucocorticoid action and resistance. J. Steroid Biochem. Mol. Biol. 83, 37-48 http://dx.doi.org/10.1016/S0960-0760(02)00263-7

Schafroth U., Godang K., Ueland T., Berg J. P., Bollerslev J. (2000): Leptin levels in relation to body composition and insulin concentration in patients with endogenous Cushing's syndrome compared to controls matched for body mass index. Endocrinol. Invest. 23, 349-355

Schmidt S., Rainer J., Ploner C., Presul E., Riml S., Kofler R. (2004): Glucocorticoid-induced apoptosis and glucocorticoid resistance: molecular mechanisms and clinical relevance. Cell Death Differ. 11 (Suppl. 1), S45-55

http://dx.doi.org/10.1038/sj.cdd.4401456

Souza K. L., Elsner M., Mathias P. C., Lenzen S., Tiedge M. (2004): Cytokines activate genes of the endocytotic pathway in insulin-producing RINm5F cells. Diabetologia 47, 1292-1302 http://dx.doi.org/10.1007/s00125-004-1435-2 
Weinhaus A. J., Bhagroo N. V., Brelje T. C., Sorenson R. L. (2000): Dexamethasone counteracts the effect of prolactin on islet function: implications for islet regulation in late pregnancy. Endocrinology 141, 1384-1393 http://dx.doi.org/10.1210/en.141.4.1384

Zhang S., Liu J., Saafi E. L., Cooper G. J. (1999): Induction of apoptosis by human amylin in RINm5F islet beta-cells is associated with enhanced expression of p53 and p21WAF1/CIP1. FEBS Lett. 455, 315-320

http://dx.doi.org/10.1016/S0014-5793(99)00894-7

Received: July 18, 2011

Final version accepted: November 22, 2011 